Research Article

\title{
Woody Species Diversity, Vegetation Structure, and Regeneration Status of the Moist Afromontane Forest of Agama in Southwestern Ethiopia
}

\author{
Abyot Dibaba $\left(\mathbb{D},{ }^{1}\right.$ Teshome Soromessa, ${ }^{2}$ Alemayehu Kefalew, ${ }^{3}$ and Admassu Addi ${ }^{4}$ \\ ${ }^{1}$ Department of Biology, Debre Berhan University, Debre Berhan, Ethiopia \\ ${ }^{2}$ Center for Environmental Science, Addis Ababa University, Addis Ababa, Ethiopia \\ ${ }^{3}$ Department of Biology, Debre Markos University, Debre Berhan, Ethiopia \\ ${ }^{4}$ Holeta Bee Research Center, Holeta, Ethiopia \\ Correspondence should be addressed to Abyot Dibaba; abyotdibaba77@yahoo.com
}

Received 29 November 2019; Revised 6 February 2020; Accepted 9 March 2020; Published 30 June 2020

Academic Editor: Panos V. Petrakis

Copyright (C) 2020 Abyot Dibaba et al. This is an open access article distributed under the Creative Commons Attribution License, which permits unrestricted use, distribution, and reproduction in any medium, provided the original work is properly cited.

\begin{abstract}
This study was conducted in Agama Forest in Kafa Zone, Southwestern Ethiopia, to assess species diversity, vegetation structure, and regeneration status of woody species. A systematic sampling technique was employed to collect vegetation data. Sixty (60) sample plots of $25 \mathrm{~m} \times 25 \mathrm{~m}$ were laid at $300 \mathrm{~m}$ intervals all along ten grids interspaced $800 \mathrm{~m}$ apart. Sample plots of $25 \mathrm{~m} \times 25 \mathrm{~m}$ were used to record $\mathrm{DBH}$ and $H$ of all woody plant species reaching a $\mathrm{DBH}>2.5 \mathrm{~cm}$ and height $>2 \mathrm{~m}$. For the inventory of seedling and sapling, two subplots of $2 \mathrm{~m} \times 5 \mathrm{~m}$ were used at the beginning and the end of the baseline on opposite sides of the main quadrat. Vegetation data such as DBH, height, seedling, and sapling density of woody species were recorded in each plot. Altogether, 72 woody plant species of 65 genera and 35 families were identified. Analysis of selected tree species showed diverse population structures. This study showed that small trees and shrubs dominated the Agama Forest, which revealed its status under a secondary regeneration stage. Study on the structure and regeneration of some woody species indicated that there are species that require urgent conservation measures. Sound management and monitoring, as well as maintenance of biodiversity and cultural and economic values of the forest, require conservation activities that encourage sustainable uses of the forest and its products.
\end{abstract}

\section{Introduction}

Ethiopia's highly variable ecology, topography, and climate make it an internationally recognized centre of biodiversity [1]. The country has around 6000 higher plant species of which about $10 \%$ are endemic $[2,3]$. The vegetation of Ethiopia has been classified into 12 types [4]. The vegetation type at Agama Forest in Southwestern Ethiopia, the subject of this paper, is part of the moist evergreen Afromontane forest that is characterized by one or more closed strata of evergreen trees that may reach heights of 30 to $40 \mathrm{~m}$.

Southwestern Ethiopia best represents remnant natural forests but those are being destroyed at an alarming rate [5]. Human-induced loss of forest cover, structure, and biodiversity is of global concern; in Ethiopia, [6] estimated rates of deforestation and forest degradation at between 150,000 and $200,000 \mathrm{ha} /$ year and this was associated with loss of forest structure, diversity, dynamics, and evolution. New investment opportunities in Southwestern Ethiopia are converting these remnant forests into other land uses such as tea and coffee plantations [7]. New settlers migrating from the northern and central parts of Ethiopia have also contributed to land use changes and forest degradation $[8,9]$.

The Shannon-Wiener index, $H$, is the most popular measure of species diversity because it scores for both species richness and evenness and is not affected by sample size $[10,11]$. In the analysis of vegetation structure, the growth stages of trees as seedlings, saplings, and mature trees as well as the distribution of size classes within a population can be essential elements of diversity that permit or deny the 
likelihood of quick recovery after disturbances [12]. The status and dynamics of woody-tree populations can be examined by conducting a size class distribution and seedling and sapling counts $[13,14]$. Healthy natural populations with continuous regeneration exhibit an exponentially decaying size class distribution, whereby trees in smaller size classes are represented in greater numbers than in larger classes. The absence or rarity of seedlings can be considered an indication of a declining population. The population structure of a tree species is indicative of its history of past disturbance and can be used to predict its future status in the forest [13]. This study investigated the woody species diversity, structure, and regeneration status of the Agama Forest in Southwestern Ethiopia. The results will be used to set conservation and management strategies for this forest.

\section{Materials and Methods}

2.1. Study Area. This study was conducted in Gimbo district of the Kafa Zone in the Southern Nations' Nationalities and Peoples' Regional State (SNNPRS), which is located $500 \mathrm{~km}$ from Addis Ababa and $30 \mathrm{~km}$ from Bonga (Figure 1). The area is centered at $7.16^{\circ} \mathrm{N}, 36.11^{\circ} \mathrm{E}$, the altitudinal range is from $1800 \mathrm{~m}$ to $2370 \mathrm{~m}$, and the topography is undulating, with valleys and rolling plateaus [15]. The size of the study forest covers about 1872 hectares (Figure 1).

The climate data between the years 2005 and 2018 recorded by the meteorological station at Bonga that is located $20 \mathrm{~km}$ south of the study area was used to describe the climatic condition of the study area. There is a unimodal rainfall pattern with eight months between March and October with rainfall $>100 \mathrm{~mm} /$ month [16]. The mean annual rainfall is $1830 \mathrm{~mm}$, and the monthly mean maximum and mean minimum temperatures are $29.6^{\circ} \mathrm{C}$ and $9.5^{\circ} \mathrm{C}$, respectively. The mean annual temperature is $19.7^{\circ} \mathrm{C}$.

The major soil groups of the study area, according to the FAO/UNESCO legend of soil classification, are Nitisols, Acrisols, and Vertisols [17]. The Nitisols are agriculturally the most important and dominant type of soils in the Kafa Zone. The Nitisols are clay-red in color and have moderate CEC and relatively high organic matter content and total nitrogen.

2.2. Vegetation Sampling. A preliminary survey was made from 30 April 2017 to 15 May 2017 to obtain an impression on the general physiognomy of the vegetation and identify sampling sites in the study area. The actual field study was conducted from 10 December 2017 to 30 April 2018. The systematic sampling design was used to collect vegetation and environmental data $[10,18,19]$. Sixty $(60)$ sample quadrats of $25 \times 25 \mathrm{~m}$ were laid at $300 \mathrm{~m}$ intervals along ten grids interspaced $800 \mathrm{~m}$ apart. Seedling and sapling inventories of all woody-tree and shrub species were recorded in two $2 \times 5 \mathrm{~m}$ subquadrats located on opposite sides of each quadrat. For all woody species of height $(H) \geq 2 \mathrm{~m}$ and diameter at breast height $(\mathrm{DBH}) \geq 2.5 \mathrm{~cm}, H$ and $\mathrm{DBH}$ were measured using a clinometer and diameter tape, respectively. Regeneration patterns were assessed using the total count of seedlings $(H \leq 50 \mathrm{~cm}$ and $\mathrm{DBH} \leq 2.5 \mathrm{~cm})$ and saplings $(H>50 \mathrm{~cm}$ and
$\mathrm{DBH} \leq 2.5 \mathrm{~cm}$ ) within the subquadrats. Geographical coordinates and altitudes were recorded for each quadrat using GPS. Plant specimens were collected, pressed, dried, and brought to the National Herbarium (ETH), Addis Ababa University, for taxonomic identification and nomenclature. These were determined by comparison with authenticated specimens housed at ETH and by referring to published volumes of the Flora of Ethiopia and Eritrea [20-25].

2.3. Data Analysis. Species diversity was calculated using the Shannon-Wiener diversity index, $H$, as

$$
H=-\sum_{i=1}^{s} p_{i} \ln p_{i}
$$

where $s$ is the number of woody species and $p_{i}$ is the proportion of individuals or the abundance of the $i^{\text {th }}$ species expressed as a proportion of the total.

Shannon's evenness, $J$, was calculated as the ratio of observed diversity, $H$, to the maximum diversity, $H_{\max }$, using the following equation:

$$
J=\frac{H}{\ln (s)}=\frac{H}{H_{\max }},
$$

where $\ln (s)=H_{\max }$

The structure of the vegetation was described using a frequency distribution of $H, \mathrm{DBH}$, and Importance Value Index (IVI). Tree or shrub density and basal area values were calculated on a per-hectare basis. For all species, IVIs were calculated as the sum of their relative density (RD), relative frequency (RF), and relative dominance (RDO) [10] where

$$
\begin{aligned}
& \mathrm{RD}=\frac{\text { the number of all individuals of a species }}{\text { the total number of all individuals }} \times 100, \\
& \mathrm{RF}=\frac{\text { the number of plots where a species occurs }}{\text { the total occurrence of all species in all plots }} \times 100, \\
& \mathrm{RDO}=\frac{\text { the basal area of a species }}{\text { total basal area }} \times 100,
\end{aligned}
$$

where the basal area of an individual was $\pi d^{2} / 4(\pi=3.14$; $d=\mathrm{DBH})$.

Five IVI classes were established: I $<1 ; \quad \mathrm{II}=1-10$; III $\geq 10-20 ;$ IV $\geq 20-30 ; \mathrm{V}>30$.

Frequency $(F)$ and density $(D)$ were calculated as [26]

$$
F=\frac{\text { no. of quadrats in which a species occurs }}{\text { total no. of quadrats examined }} \times 100 \text {. }
$$

Species were grouped into five frequency classes: $A=0-20 \% ; \quad B=21-40 \% ; \quad C=41-60 \% ; \quad D=61-80 \% ; \quad E=$ $81-100 \%$ :

$$
D=\frac{\text { total no. of individuals of a species found }}{\text { total area examined }} .
$$

Species were classified into six density classes: $A \leq 1$; $B \geq 1-10 ; C \geq 10-20 ; D \geq 20-35 ; E \geq 35-50 ; F \geq 50$ individuals per hectare. 


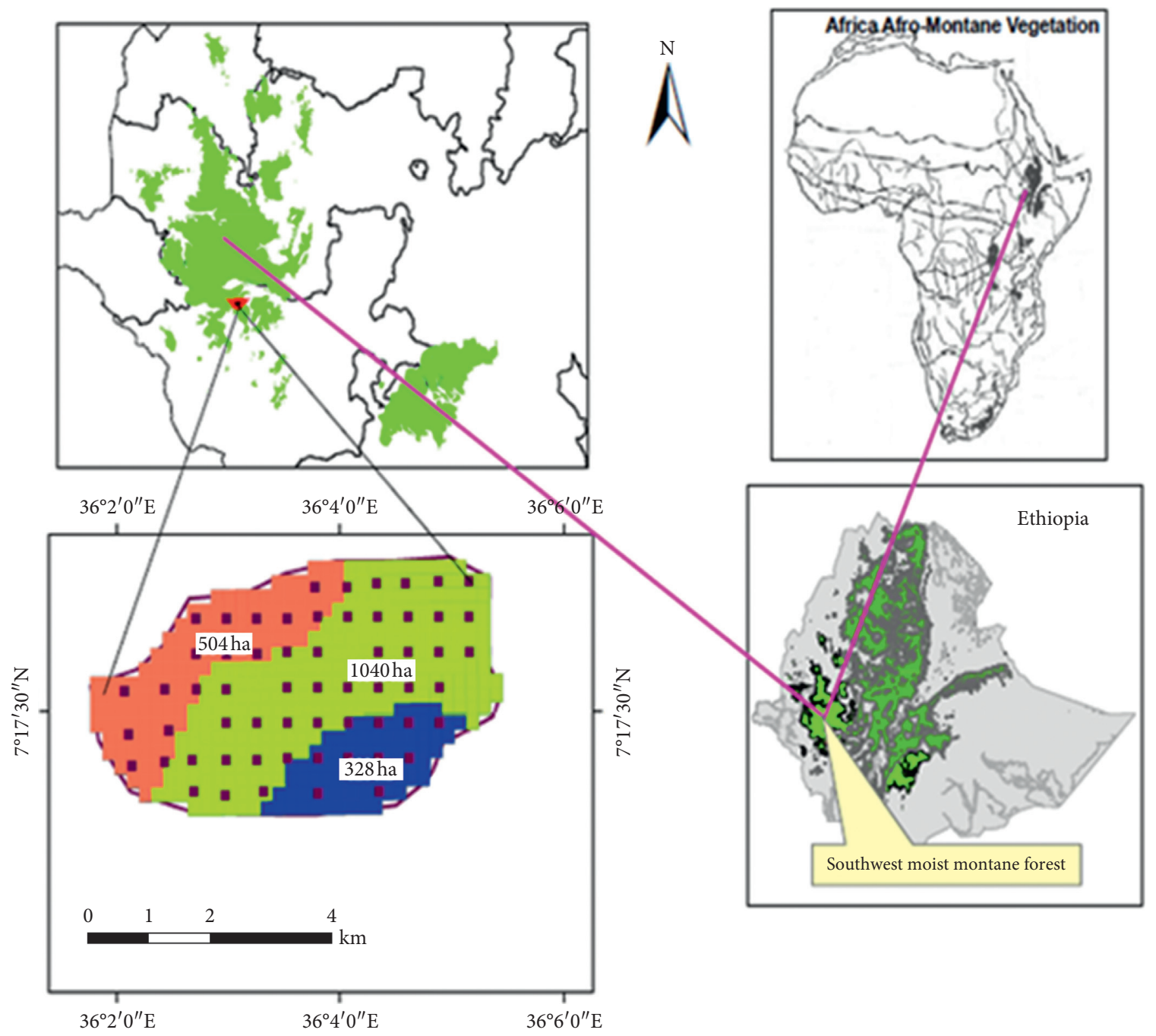

Elevation (meter)

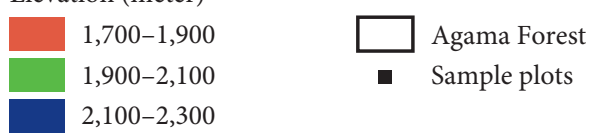

Figure 1: Map and sample plots of the study area.

The vertical stratification of trees in Agama Forest was examined following the IUFRO classification scheme [27] where three simplified vertical structures are distinguished: the upper (individuals $>2 / 3$ top height), middle (individuals between $1 / 3$ and $2 / 3$ top height), and lower (individuals $<1 /$ 3 top height) storey.

To interpret the dynamics of woody species in the forest, the population structures of selected species were expressed as a frequency of individuals against established $\mathrm{DBH}$ classes. The emerging patterns of diameter class distribution were also used to interpret the recruitment processes of a given species. Species were divided into seven $H$ and DBH classes. To use the regeneration analysis for priority setting, the species considered in the study area were classified into three groups based on the density of the total regeneration.

\section{Results}

3.1. Woody Species Diversity. Seventy-two woody plant species belonging to 35 families and 65 genera were recorded (Table 1). Of these, 43 species were trees, 18 were shrubs, and 12 were lianas. Rubiaceae was the most common family with $8(11.0 \%$ contribution) species in $8(12.3 \%)$ genera. Acanthaceae and Euphorbiaceae were the second most common, each with $5(6.9 \%)$ species in $5(7.7 \%)$ genera. The Rutaceae had 4 species in 4 genera and the Fabaceae 4 species in 3 genera. The Araliaceae, Celastraceae, Dracenaceae, Oleaceae, and Rosaceae contributed 3 species each and the remaining 25 families $<3$ species each. The Shannon-Wiener diversity index and Shannon's evenness values were 3.25 and 0.78 , respectively. 
TABle 1: List of woody species in Agama moist Afromontane forest.

\begin{tabular}{|c|c|c|c|c|}
\hline No. & Species name & Family & ${ }^{*}$ Local name & Habit \\
\hline 1 & Acanthopale ethio-germanica Ensermu & Acanthaceae & Huxxo & Shrub \\
\hline 2 & Acanthus eminens C.B.Clarke & Acanthaceae & Pheecco & Shrub \\
\hline 3 & Alangium chinense (Lour.) Harms & Alangiaceae & Shotto & Tree \\
\hline 4 & Albizia gummifera (J.F.Gmel.) C.A. Sm. & Fabaceae & Caatto & Tree \\
\hline 5 & Albizia Schimperiana Oliv. & Fabaceae & Caatto & Tree \\
\hline 6 & Allophylus abyssinicus (Hochst.) Radlk. & Sapindaceae & Sheeo & Tree \\
\hline 7 & Apodytes dimidiata E. Mey. ex Arn. & Icacinaceae & Wundifo & Tree \\
\hline 8 & Bersama abyssinica Fresen. & Melianthaceae & Booqqoo & Tree \\
\hline 9 & Brillantaisia madagascariensis T. Anders. ex Lindau & Acanthaceae & Huxxo & Shrub \\
\hline 10 & Buddleja polystachya Fresen. & Loganiaceae & Ataaro & Tree \\
\hline 11 & Canthium oligocarpum Hiern & Rubiaceae & Xixiribbo & Tree \\
\hline 12 & Cassipourea malosana (Baker) Alston & Rhizophoraceae & Woraalo & Tree \\
\hline 13 & Celtis africana Burm.f. & Ulmaceae & Uffo & Tree \\
\hline 14 & Clausena anisata (Willd.) Benth. & Rutaceae & Immico & Shrub \\
\hline 15 & Clematis longicauda Steud. ex A. Rich & Ranunculaceae & Shaggee qombo & Liana \\
\hline 16 & Clematis simensis Fresen. & Ranunculaceae & Phi’o Qombo & Liana \\
\hline 17 & Coffea arabica L. & Rubiaceae & Bunoo & Tree \\
\hline 18 & Combretum paniculatum Vent. & Combretaceae & Baggo & Liana \\
\hline 19 & Cordia africana Lam. & Boraginaceae & Di'o & Tree \\
\hline 20 & Croton macrostachyus Del. & Euphorbiaceae & Waagoo & Tree \\
\hline 21 & Cyathea manniana Hook. & Cyatheaceae & Sheshino & Tree \\
\hline 22 & Dalbergia lactea Vatke & Fabaceae & Gimiro & Liana \\
\hline 23 & Dombeya torrida (J.F.Gmel.) P. Bamps & Sterculiaceae & Shawakko & Tree \\
\hline 24 & Dracaena afromontana Mildbr. & Dracaenaceae & Coqimato & Tree \\
\hline 25 & Dracaena fragrans (L.) Ker Gawl. & Dracaenaceae & Emoo & Shrub \\
\hline 26 & Dracaena steudneri Engler & Dracaenaceae & Yuddo & Tree \\
\hline 27 & Ehretia cymosa Thonn. & Boraginaceae & Wagaamo & Tree \\
\hline 28 & Ekebergia capensis Sparrm & Meliaceae & Ororo & Tree \\
\hline 29 & Elaeodendron buchananii (Loes.) Loes. & Celastraceae & Washo & Tree \\
\hline 30 & Erythrococca trichogyne (Muell Arg.) Prain & Euphorbiaceae & Biccre kucco & Shrub \\
\hline 31 & Euphorbia ampliphylla Pax & Euphorbiaceae & Gachoo & Tree \\
\hline 32 & Fagaropsis angolensis (Engl.) Dale & Rutaceae & Yaayyo & Tree \\
\hline 33 & Ficus sur Forssk. & Moraceae & Caaro & Tree \\
\hline 34 & Flacourtia indica (Burm.f.) Merrill & Flacourtiaceae & Anam shiko & Tree \\
\hline 35 & Galiniera saxifraga (Hochst.) Bridson & Rubiaceae & Diidoo & Tree \\
\hline 36 & Hippocratea pallens Planch. ex Oliv. & Celastraceae & Qawe qombo & Liana \\
\hline 37 & Ilex mitis (L.) Radlk. & Aquifoliaceae & Qetoo & Tree \\
\hline 38 & Jasminum abyssinicum Hochst. ex DC. & Oleaceae & Hawute qombo & Liana \\
\hline 39 & Justicia schimperiana (Hochst. ex Nees)T. Anders & Acanthaceae & Sharsharo & Shrub \\
\hline 40 & Landolphia buchananii (Hall.f.) Stapf. & Apocynaceae & Yame qombo & Liana \\
\hline 41 & Lepidotrichilia volkensii (Gurke) Leroy & Meliaceae & Shahiyo & Tree \\
\hline 42 & Macaranga capensis (Baill.) Sim & Euphorbiaceae & Shakkaro & Tree \\
\hline 43 & Maesa lanceolata Forssk. & Myrsinaceae & Caggo & Shrub \\
\hline 44 & Maytenus gracilipes (Welw. ex Oliv.) Exell & Celastraceae & Shikko & Shrub \\
\hline 45 & Millettia ferruginea (Hochst.) Baker & Fabaceae & Bibero & Tree \\
\hline 46 & Ocotea kenyensis (Chiov.) Robyns \& Wilczek & Lauraceae & Najjo & Tree \\
\hline 47 & Olea capensis L. & Oleaceae & Shigiyo & Tree \\
\hline 48 & Olea welwitschii (Knobl.) Gilg \& Schellenb. & Oleaceae & Yaahoo & Tree \\
\hline 49 & Oxyanthus speciosus DC. & Rubiaceae & Opharo & Shrub \\
\hline 50 & Pavetta abyssinica Fresen. & Rubiaceae & - & Shrub \\
\hline 51 & Phoenix reclinata Jacq. & Araliaceae & Yabbo & Tree \\
\hline 52 & Pittosporum viridiflorum Sims & Pittosporaceae & Sholloo & Shrub \\
\hline 53 & Polyscias fulva (Hiern) Harms & Araliaceae & Karasho & Tree \\
\hline 54 & Pouteria adolfi-friederici (Engl.) Baehni & Sapotaceae & Qararo & Tree \\
\hline 55 & Premna schimperi Engl. & Verbenaceae & Xumo & Shrub \\
\hline 56 & Prunus africana (Hook.f.) Kalkm. & Rosaceae & Omo & Tree \\
\hline 57 & Psychotria orophila Petit & Rubiaceae & Aa'imaato & Shrub \\
\hline 58 & Rhamnus prinoides L’Herit. & Rhamnaceae & Geeshoo & Shrub \\
\hline 59 & Rothmannia urcelliformis (Hiern) Robyns & Rubiaceae & Dibo & Tree \\
\hline 60 & Rubus apetalus Poir. & Rosaceae & Garoo & Liana \\
\hline
\end{tabular}


TABLE 1: Continued.

\begin{tabular}{lccc}
\hline No. & Species name & Family & *Local name \\
\hline 61 & Rubus steudneri Schweinf. & Habit \\
62 & Rytigynia neglecta (Hirn) Robyns & Rosaceae & Liana \\
63 & Sapium ellipticum (Krauss) Pax & Rubiaceae & Naxaacho \\
64 & Shrub \\
65 & Sericostachys Scandens Gilg \&Lopr. & Shaddo & Tree \\
66 & Syzygium guineense (Willd.) DC. & Araliaceae & Tree \\
67 & Teclea nobilis Del. & Amaranthaceae & Shuddii \\
68 & Tiliacora troupinii Cuf. & Myrtaceae & Yinoo \\
69 & Trema orientalis (L.) Bl. & Rutaceae & Thangaro \\
70 & Vepris dainellii (Pic. Serm.) Kokwaro & Menispermaceae & Caamee qombo \\
71 & Vernonia amygdalina Del. & Tree \\
72 & Vernonia auriculifera Hiern & Rutaceae & Liana \\
\hline
\end{tabular}

${ }^{*}$ Local name $=$ Kafinono

3.2. Density of Woody Species. The density, $D$, of trees and shrubs with $H>2 \mathrm{~m}$ and $\mathrm{DBH}>2.5 \mathrm{~cm}$ was 1446 individuals per hectare. Twelve species were in density class $A$ and 20, $10,10,3$, and 7 species in classes $B, C, D, E$, and $F$, respectively. The seven most abundant species in the density class $F\left(D>50 \mathrm{ha}^{-1}\right)$ were Coffea arabica, Elaeodendron buchananii, Millettia ferruginea, Olea capensis, Oxyanthus speciosus, Syzygium guineense, and Vepris dainellii.

The $D$ of trees and shrubs with DBH $10-20 \mathrm{~cm}$ and $\mathrm{DBH}>20 \mathrm{~cm}$ were, respectively, 556 and 281 individuals per hectare. Accordingly, the ratio of individuals with $\mathrm{DBH}$ $10-20 \mathrm{~cm}$ (a) to $\mathrm{DBH}>20 \mathrm{~cm}$ (b) was 2.0 .

Comparison of trees and shrub densities with $\mathrm{DBH}$ $10-20 \mathrm{~cm}(\mathrm{a}), \mathrm{DBH}>20 \mathrm{~cm}(\mathrm{~b})$, and the ratio (a/b) for Agama Forest with 5 other forests in Ethiopia is given in Table 2.

3.3. Frequency. Twenty-seven, 17, 8, 4, and 6 species were recorded in frequency classes $A, B, C, \mathrm{D}$, and $E$, respectively. The six most frequently occurring species in class $E$ were Elaeodendron buchananii, Olea capensis, Olea welwitschii, Oxyanthus speciosus, Syzygium guineense, and Vepris dainellii.

3.4. Basal Area. The total basal area was $80.8 \mathrm{~m}^{2} /$ ha. The highest $(33.3 \%)$ and the lowest $(0.001 \%) \mathrm{BA} \mathrm{ha}^{-1}$ were contributed by Olea welwitschii and Pavetta abyssinica, respectively. Elaeodendron buchananii, Olea welwitschii, Sapium ellipticum, Schefflera abyssinica, and Syzygium guineense covered $71.4 \%$ of the total basal area.

3.5. Important Value Index (IVI). Ten species contributed $59.9 \%$ of the IVI. These were in decreasing order: Olea welwitschii, Elaeodendron buchananii, Olea capensis, Syzygium guineense, Schefflera abyssinica, Vepris dainellii, Oxyanthus speciosus, Millettia ferruginea, Sapium ellipticum, and Coffea arabica. About 39\% of the IVI was contributed by the remaining 52 species. Percentage values in the five IVI classes, I to $\mathrm{V}$, were $2.5 \%, 43 \%, 18.9 \%, 21.9 \%$, and $13.7 \%$, respectively. Most species were in classes I and II.

3.6. Vertical Stratification. The tallest tree was an individual of Olea welwitschii with $H=46 \mathrm{~m}$. The lower storey
TABle 2: Comparisons of tree and shrub densities with $\mathrm{DBH}$ $10-20 \mathrm{~cm}$ (a) and tree density with $\mathrm{DBH}>20 \mathrm{~cm}$ (b) from Agama Forest with 5 other moist Afromontane forests in Ethiopia.

\begin{tabular}{lcccc}
\hline \multirow{2}{*}{ Forests } & \multicolumn{2}{c}{ Density } & Ratio & Sources \\
& $(\mathrm{a})$ & (b) & $\mathrm{a} / \mathrm{b}$ & \\
\hline Belete & 305.1 & 149.0 & 2.04 & {$[28]$} \\
Gelesha & 315.4 & 244.6 & 1.29 & {$[29]$} \\
Komto & 330.0 & 215.0 & 1.53 & {$[30]$} \\
Masha & 633.0 & 286.0 & 2.21 & {$[31]$} \\
Menna Angetu & 292.0 & 139.0 & 2.10 & {$[32]$} \\
Agama & 556.3 & 280.9 & 1.98 & Present study \\
\hline
\end{tabular}

contained the highest number of species, 60 , and stem density, 1309/ha, and the upper the lowest, 7 and 17/ha, respectively; the middle storey was intermediate, 26 and 11/ ha, respectively (Table 3 ).

The seven tree species that occupied the upper storey were Apodytes dimidiata, Olea welwitschii, Pouteria adolfi-friederici, Prunus africana, Sapium ellipticum, Schefflera abyssinica, and Syzygium guineense, and the 11 in the middle storey were Albizia gummifera, Croton macrostachyus, Elaeodendron buchananii, Fagaropsis angolensis, Ficus sur, Ilex mitis, Macaranga capensis, Millettia ferruginea, Ocotea kenyensis, Phoenix reclinata, and Polyscias fulva. The main species in the lower storey, shrubs and small trees, were Allophylus abyssinica, Coffea arabica, Cyathea manniana, Clausena anisata, Dombeya torrida, Dracaena afromontana, Ehretia cymosa, Erythrococca trichogyne, Maesa lanceolata, Maytenus gracilipes, Olea capensis, Oxyanthus speciosus, Rothmannia urcelliformis, Rytigynia neglecta, Teclea nobilis, and Vepris dainellii.

3.7. Height and DBH Class Distribution. The $H$ and $\mathrm{DBH}$ class distributions of all individuals in the different size classes were an inverted J shape. Thus the majority of species had the greatest number of individuals with relatively low $H$ and $\mathrm{DBH}$ with a gradual decrease in numbers of both with increasing $H$ and $\mathrm{DBH}$. About $63 \%$ of individuals were found in the first height class $(2.5-5 \mathrm{~m})$; only a few individuals, about $1 \%$, attained heights $>30 \mathrm{~m}$. DBH distribution showed that about $81 \%$ of individuals were in the DBH class $<20 \mathrm{~cm}$, and a very small proportion (1.2\%) reached $\mathrm{DBH}>110 \mathrm{~cm}$. 
Table 3: Density and number of woody species by storey in Agama Forest.

\begin{tabular}{|c|c|c|c|c|}
\hline Storey & Height (m) & Density (no. of stems/ha) & Percentage & Species number \\
\hline Lower & $2-15$ & 1309.3 & 87.88 & 60 \\
\hline Middle & $15-30$ & 163.74 & 10.99 & 26 \\
\hline Upper & $>30$ & 16.8 & 1.33 & 7 \\
\hline
\end{tabular}

3.8. Population Structure of Agama Forest. There were four main patterns of population structure (Figures 2(a)-2(d)). The first was a bell-shaped distribution, in which the number of individuals in the middle diameter classes is highest, e.g., Olea welwitschii and Syzygium guineense. The second was a J-shaped distribution, in which the number of individuals increases with diameter class, e.g., Schefflera abyssinica, Cyathea manniana, and Rytigynia neglecta. The third was formed with species showing an inverted J shape, a pattern where the highest frequency is in the lower diameter classes and it decreases towards the higher diameter classes, e.g., Elaeodendron Buchananii, Olea capensis, Vepris dainellii, Oxyanthus speciosus, and Teclea nobilis. The fourth pattern had no individual in DBH class one, an abrupt increase from $\mathrm{DBH}$ class two to the middle classes, and an abrupt decrease from the middle to the higher classes, e.g., Sapium ellipticum, Croton macrostachyus, and Poliscas fulva (Figure 2(d)).

3.9. Regeneration Status of Agama Forest. Total density of seedling, sapling, and tree/shrubs was $3378 \mathrm{ha}^{-1}, 1888 \mathrm{ha}^{-1}$, and $1486 \mathrm{ha}^{-1}$, respectively. Out of 54 trees and shrubs of $\mathrm{DBH}>2.5 \mathrm{~cm}, 6$ were not represented as seedlings and 11 not represented as saplings. Nine species, Coffea arabica, Elaeodendron buchananii, Galiniera saxifraga, Maytenus gracilipes, Millettia ferruginea, Olea capensis, Oxyanthus speciosus, Phoenix reclinata, and Vepris dainellii, contributed $54.3 \%$ and $55.2 \%$ of the total seedling and sapling count, respectively.

Regeneration status was represented by five distribution patterns (Figure 3): (I) seedling $>$ sapling $>$ tree/shrub, a pattern exhibited by Albizia gummifera, Bersama abyssinica, Canthium oligocarpum, Coffea arabica, and Millettia ferruginea (Figure 3(a)); (II) seedling > sapling < tree/shrub by Elaeodendron buchananii, Oxyanthus speciosus, Erythrococca trichogyne, and Vepris dainellii (Figure 3(b)); (III) seedling < sapling < tree/shrub by Dracaena afromontana, Ficus sur, Ocotea kenyensis, Olea welwitschii, and Sapium ellipticum (Figure 3(c)); (IV) no individual in either seedling or sapling stages but many trees/shrubs by Buddleja polystachya, Euphorbia ampliphylla, Fagaropsis angolensis, Flacourtia indica, Premna schimperi, Rhamnus prinoides, and Trema orientalis (Figures 3(d) and 3(e)); (V) with no individual in seedling and sapling stages but relatively many individuals in tree/shrub stage, e.g., Alangium chinense, Cordia africana, Cyathea manniana, Ekebergia capensis, and Schefflera abyssinica (Figure 3(f)).

Three priority classes based on the total density of seedlings and saplings were established for conservation: class 1 with no seedling or sapling, class 2 with density of seedlings and saplings $>0$ but $<50$ individuals $\mathrm{ha}^{-1}$, and class 3 with density of seedlings and saplings $>50$ individuals ha ${ }^{-1}$ (Table 4).

\section{Discussion}

4.1. Floristic Diversity. Seventy-two (72) species of shrubs, lianas, or trees were recorded. Among the tree species, two, Vepris dainellii and Millettia ferruginea, are endemic to Ethiopia. The Shannon-Weiner diversity and evenness indexes were 3.25 and 0.78 , respectively. Thus, the species mix at Agama is representative of a forest with high species diversity [10] and the species are well represented across the extent of the forest.

4.2. Vegetation Structure. The ratio of $\mathrm{DBH}>10 \mathrm{~cm}$ to $\mathrm{DBH}>20 \mathrm{~cm}$ (a/b ratio) was 2.0 and indicative of the predominance of small-sized individuals in the forest. This was largely due to the high density of Olea capensis and Vepris dainellii. This ratio can also be used as a measure of size class distribution [33] and shows that, in Ethiopia, Agama Forest is comparable to moist Afromontane forests at Belete, Masha, and Menna Angetu, but with a greater predominance of small-sized individuals than those at Gelesha and Komto. That the proportion of individuals of $\mathrm{DBH}$ between 2.5 and $\leq 10 \mathrm{~cm}$ was $42.1 \%$ suggests that Agama Forest is in a secondary stage of development.

Frequency provides an approximate indication of the homogeneity of a stand [10]. High values in higher frequency classes $(D$ and $E$ ) and low values in lower frequency classes $(A$ and $b$ ) indicate constant or similar species composition. On the other hand, high values in lower frequency classes and low values in higher frequency classes indicate a high degree of floristic heterogeneity [27]. In this study, high values were obtained in lower frequency classes, which showed the existence of high degree of floristic heterogeneity in Agama Forest.

Elaeodendron buchananii, Olea welwitschii, Sapium ellipticum, Schefflera abyssinica, and Syzygium guineense occupied $>70 \%$ of the total basal area and can be considered the most important species in Agama Forest. A basal area provides a better measure of the relative importance of the species than simple stem count [34]. Thus, species with the largest contribution in a basal area can be considered the most important woody species in the study area.

Important Value Index (IVI) permits a comparison of species in a given forest type and depicts the sociological structure of a population in its totality in the community. It often reflects the extent of dominance, occurrence, and abundance of a given species in relation to other associated species in an area [10]. It is also important to compare the ecological significance of a given species. Therefore, it is a good index for summarizing vegetation characteristics and ranking species for management and conservation practices. Important Value Index combines data for three parameters 


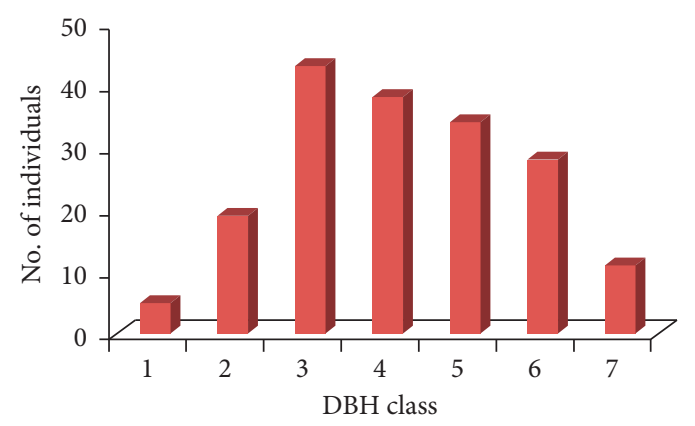

(a)

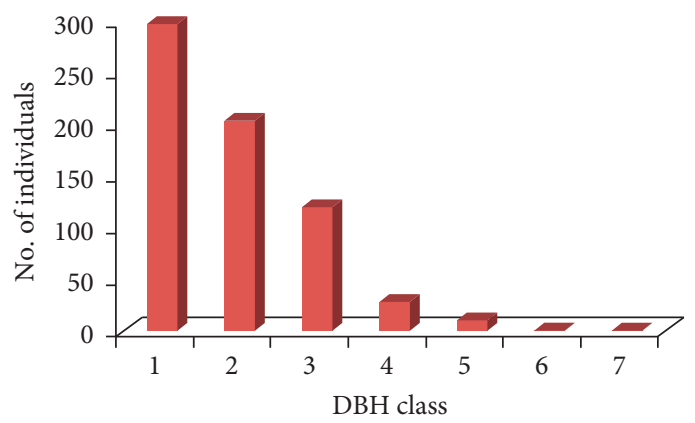

(c)

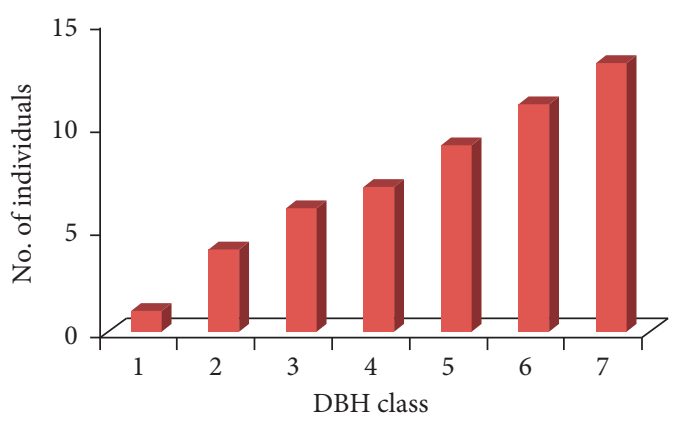

(b)

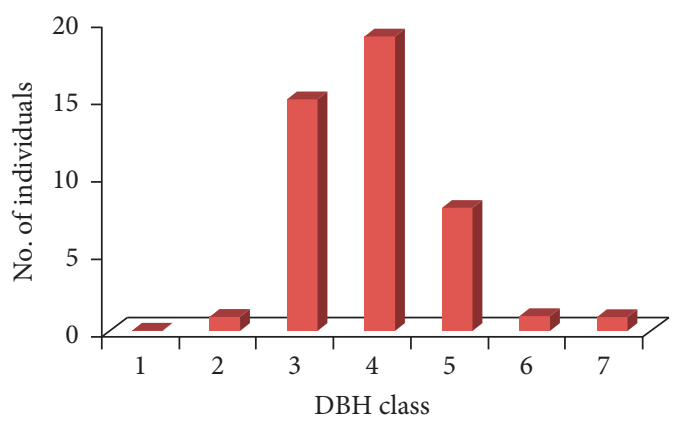

(d)

Figure 2: (a-d) Pattern of frequency distribution of selected tree species over DBH classes (DBH classes: $1=2.5-10 \mathrm{~cm} ; 2=10.01-20 \mathrm{~cm}$; $3=20.01-50 \mathrm{~cm} ; 4=50.01-80 \mathrm{~cm} ; 5=80.01-110 \mathrm{~cm} ; 6=110.01-140 \mathrm{~cm} ; 7 \geq 140 \mathrm{~cm}$ ). (a) Olea welwitschii. (b) Schefflera abyssinica. (c) Elaeodendron Buchananii. (d) Sapium ellipticum.

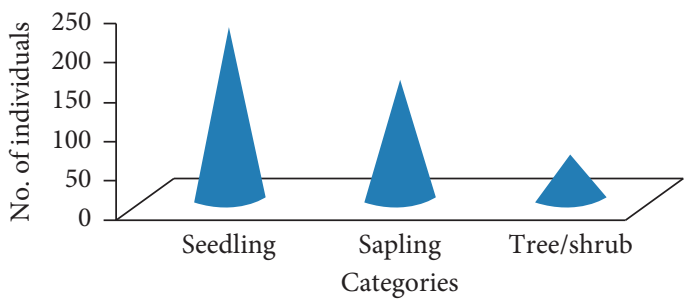

(a)

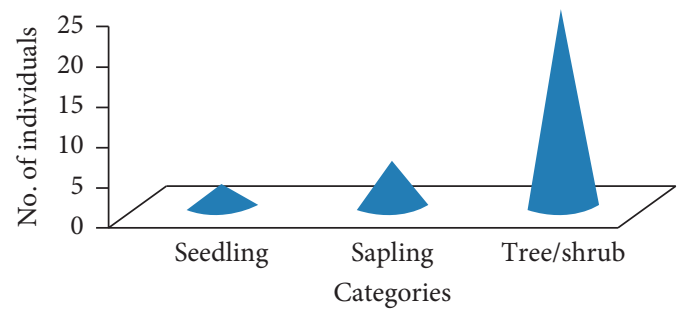

(c)

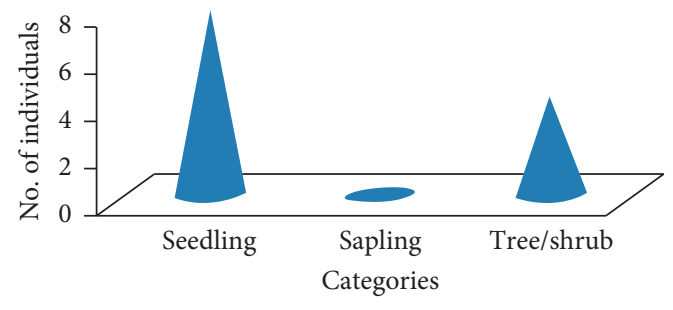

(e)

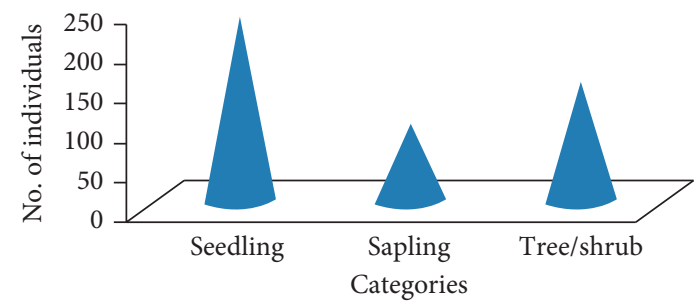

(b)

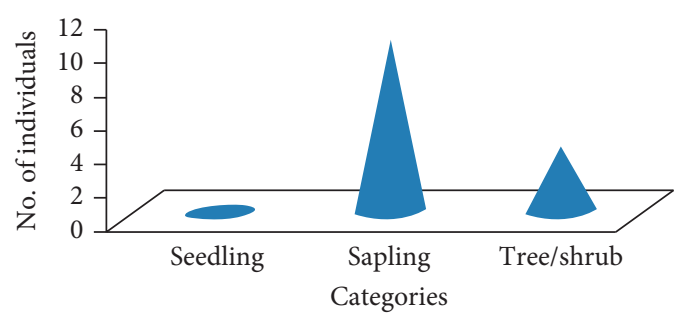

(d)

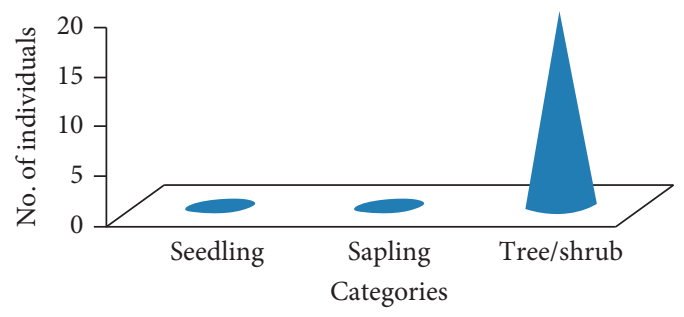

(f)

Figure 3: (a-f) Seedlings, saplings, and tree/shrub distribution of some selected species occurring in Agama Forest. (a) Coffea arabica. (b) Vepris dainellii. (c) Ficus sur. (d) Flacourtia indica. (e) Buddleja polystachya. (f) Schefflera abyssinica. 
TABLE 4: Species conservation priority classes.

\begin{tabular}{|c|c|c|c|}
\hline Priority class 1 & Priority class 2 & \multicolumn{2}{|c|}{ Priority class 3} \\
\hline Alangium chinense & Cassipourea malosana & Albizia gummifera & Maesa lanceolata \\
\hline Buddleja polystachya & Celtis africana & Allophylus abyssinica & Maytenus gracilipes \\
\hline Cordia africana & Dombeya torrida & Apodytes dimidiata & Millettia ferruginea \\
\hline Cyathea manniana & Ehretia cymosa & Bersama abyssinica & Olea capensis \\
\hline Ekebergia capensis & Erythrococca trichogyne & Canthium oligocarpum & Oxyanthus speciosus \\
\hline Euphorbia ampliphylla & Ficus sur & Clausena anisata & Phoenix reclinata \\
\hline Fagaropsis angolensis & Ocotea kenyensis & Coffea arabica & Psychotria orophila \\
\hline Flacourtia indica & Olea welwitschii & Croton macrostachyus & Rothmannia urcelliformis \\
\hline Premna schimperi & Pittosporum viridiflorum & Dracaena steudneri & Rytigynia neglecta \\
\hline Rhamnus prinoides & Polyscias fulva & Dracaena afromontana & Syzygium guineense \\
\hline Schefflera abyssinica & Pouteria adolfi-friederici & Elaeodendron buchananii & Teclea nobilis \\
\hline \multirow[t]{4}{*}{ Trema orientalis } & Prunus africana & Galiniera saxifraga & Vepris dainellii \\
\hline & Sapium ellipticum & Ilex mitis & \\
\hline & Vernonia amygdalina & Lepidotrichilia volkensii & \\
\hline & Vernonia auriculifera & Macaranga capensis & \\
\hline
\end{tabular}

(relative frequency, relative density, and relative abundance) [35]. We pointed out that Important Value Index gives a more realistic figure of dominance from the structural point of view. It is useful to compare the ecological significance of species [27]. In the present study, 59.92\% of the IVI was contributed by Olea welwitschii, Elaeodendron buchananii, Olea capensis, Syzygium guineense, Schefflera abyssinica, Vepris dainellii, Oxyanthus speciosus, Millettia ferruginea, Sapium ellipticum, and Coffea arabica. These species were abundant, frequent, and dominant in Agama Forest.

In Agama Forest, distribution of all individuals in different height and $\mathrm{DBH}$ classes indicated an inverted J-shaped curve, which shows a normal population structure with a high number of individuals in the lower size classes and only a few individuals in the higher size classes. This pattern is an indicator of healthy regeneration of the forest and species and shows a good reproduction and recruitment capacity. Even though the overall height and DBH distribution revealed inverse $J$ shape, different population dynamics for different species were in this study.

Information on the population structure of a tree species indicates the history of the past disturbance to that species and the environment and, hence, is used to forecast the future trend of the population of that particular species [13]. Population structure is an extremely useful tool for orienting management activities and perhaps most important for assessing both the potential of a given resource and the impacts of resource extraction [13]. In this study, four patterns population distributions based on $\mathrm{DBH}$ were revealed for selected woody species. These are J-shaped, bellshaped, inverted J-shaped, and irregular shaped. The J-shaped patterns show poor reproduction and hampered regeneration due to the fact that either most trees are not producing seeds due to age or there are losses due to predators after reproduction (e.g., Schefflera abyssinica). A bell shape follows a Gauss distribution pattern. This pattern indicates a poor reproduction and recruitment of species, which may be associated with the overharvesting of seed bearing individuals (e.g., Olea welwitschii). Bell-shaped or variable size class distribution has been attributed to a disturbed forest where regeneration is hampered [36]. An inverted J-shaped distribution pattern of species is considered as an indication of stable population status or good regeneration status [37]. An irregular shaped pattern characterized by no individual in $\mathrm{DBH}$ class one, with an abrupt increase from DBH class two to the middle classes and with an abrupt decrease from the middle to the higher classes (e.g., Sapium ellipticum), might reflect limited regeneration, possibly due to human disturbance, livestock trampling or browsing, and other biotic and abiotic factors.

4.3. Regeneration Status. Regeneration refers to the process of silvigenesis by which trees and forests survive over time [38]. The population structure along different developmental stage of a species in a forest can express its regeneration behavior [39]. The population structure, described by the existence of sufficient population of seedlings, saplings, and adults, shows successful regeneration of forest species [39].

In this study, five distribution patterns of regeneration status were observed from the 54 woody species investigated for regeneration. (1) Seedling $>$ sapling $>$ tree/shrub state (e.g., Millettia ferruginea): this pattern indicates good regeneration. (2) Seedling > sapling < tree/shrub state (e.g., Elaeodendron buchananii): this pattern represents fair regeneration and recruitment of the species. (3) Seedling < sapling < tree/shrub state (e.g., Ficus sur): this pattern shows poor reproduction and hampered regeneration either due to the fact that most trees are not producing seeds as a result of their old age or there has been a loss of seeds by predators after reproduction. For instance, the fruits of Ficus sur were usually eaten as food by many animals including humans, which might be a reason for this pattern. (4) With no individual either in seedling or sapling stages but relatively many individuals in tree/shrub stage (e.g., Fagaropsis angolensis and Flacourtia indica): this pattern also shows poor reproduction and hampered regeneration. (5) With no individual in seedling and sapling stages but relatively many individuals in tree/shrub stage (e.g., Ekebergia capensis and Schefflera abyssinica): species exhibiting this pattern were not regenerating. Even though Schefflera abyssinica exhibits this pattern of regeneration, it 
is difficult to conclude the species was not regenerating. The main reason is that it grows as an epiphyte mainly on other tree species and finally overtakes it to become an independent tree; as a result, the seedling and sapling stages are not visible on the ground [40].

From the three classes established for priority setting based on their regeneration status for the sake of conservation activities, those species under class 1 and class 2 are recommended to be given the highest priority. Thus, all stakeholders at both national and regional level should participate in the conservation endeavor of these species which can encompass both in situ and ex situ conservation.

\section{Conclusion}

Description of floristic diversity of woody species in Agama Forest revealed the presence of high species diversity. Of the species recorded in this forest, two tree species, Vepris dainellii and Millettia ferruginea, are endemic to Ethiopia. Structural analysis and assessment of regeneration status of woody species in this forest showed that the overall ecological condition of the forest was healthy. However, structural analysis and assessment of regeneration of some species revealed that there are species which exhibit abnormal population structure and abnormal pattern of regeneration which in turn necessitates conservation and management of these species. The in situ conservation strategy, which has been implemented by FARM Africa, an NGO that has been engaged in conservation endeavor of the study forest, in the form of participatory forest management (PFM), should be strengthened via collaboration of all potential stakeholders to reverse the unhealthy population structure and regeneration status of woody species.

\section{Data Availability}

Part of the data used in this research are included and attached as Additional Files 1, 2, and 3. Thus, the data used for this manuscript are available.

\section{Conflicts of Interest}

The authors declare that they have no conflicts of interest.

\section{Acknowledgments}

The authors would like to acknowledge Addis Ababa University for providing financial support and logistics to conduct this research.

\section{Supplementary Materials}

Additional File 1: data were used to calculate density, frequency, basal area, and relative density, relative frequency, and relative basal area. Additional File 2: data were used to calculate Importance Value Index (IVI). Additional file 3: data were used to determine regeneration status and priority class for conservation. (Supplementary Materials)

\section{References}

[1] EPA, Conservation Strategy of Ethiopia, EPA, Addis Ababa, Ethiopia, 1997.

[2] I. Hedberg, I. Friis, and E. Person, Flora of Ethiopia and Eritrea Volume 8: General Part and Index to Vol 1-7, The National Herbarium and Uppsala, Sweden, Addis Ababa, Ethiopia, 2009.

[3] E. Kelbessa and S. Demissew, "Diversity of vascular plant taxa of the flora of Ethiopia and Eritrea," Ethiopian Journal of Biological Sciences, vol. 13, pp. 37-45, 2014.

[4] I. Friis, S. Demissew, and P. van Breugel, A New Potential Vegetation Map of Ethiopia in 1:2,000,000, Det Kongelige Danske Videnskabers Selskab, Copenhagen, Denmark, 2010.

[5] M. Reusing, "Change detection of natural high forests in Ethiopia using remotesensing and gis techniques," in International Archives of Photogrammetry and Remote Sensing, vol. 33, Amsterdam, The Netherlands, 2000.

[6] M. Reusing, Monitoring of Natural High Forests in Ethiopia, Ministry of Agriculture and GTZ, Addis Ababa, Ethiopia, 1998.

[7] K. Yeshitela and T. Bekele, "Plant community analysis and ecology of Afromontane and transitional rainforest vegetation of southwestern Ethiopia," SINET: Ethiopian Journal of Science, vol. 25, no. 2, pp. 155-175, 2002.

[8] M. Ezra, "Demographic responses to ecological degradation and food insecurity: drought-prone areas in northern Ethiopia," Doctoral dissertation, University of Groningen, PDOD Publications, Amsterdam, The Netherlands, 1997.

[9] M. Lemenih and T. Woldemariam, "Review of forest, woodland and bushland resources in Ethiopia up to 2008," in Ethiopian Environment Review No. 1, S. Edwards, Ed., Forum for Environment, Addis Ababa, Ethiopia, 2010.

[10] M. Kent, Vegetation Description and Data Analysis. A Practical Approach, John Wiley \& Sons, Chichester, UK, 2012.

[11] C. J. Krebs, Ecological Methodology, Addison Welsey Educational Publishers, Boston, MA, USA, 2nd edition, 1999.

[12] J. L. Harper, Population Biology of Plants, Academic Press, London, UK, 1982.

[13] C. M. Peters, "The ecology and management of non-timber forest resources," World Bank Technical Report No. 322, World Bank, Washington, DC, USA, 1996.

[14] U. Shankar, "A case of high tree diversity in a Sal (Shorea robusta) dominated lowland forest of Eastern Himalaya: floristic composition, regeneration and conservation," Current Science, vol. 81, no. 7, pp. 776-786, 2001.

[15] EVDSA. Ethiopian Valleys Development Studies Authority. Addis Ababa, Ethiopia, 1996.

[16] NMSA, National Meteorological Service Agency, Ethiopia, 2018.

[17] EMA, National Atlas of Ethiopia, Ethiopian Mapping Authority, Addis Ababa, Ethiopia, 1988.

[18] M. Dumbois and H. Ellenberg, Aims and Methods of Vegetation Ecology, John Willey and Sons, New York, NY, USA, 1974.

[19] B. McCune and J. B. Grace, Analysis of Ecological Communities, MjM Software Design, Gleneden Beach, OR, USA, 2002.

[20] S. Edwards, M. Tadesse, and I. Hedberg, Flora of Ethiopia and Eritrea: Canellaceae to Euphorbiaceae, Vol. 2, Addis Ababa: The National Herbarium, Addis Ababa University, Addis Ababa, Ethiopia, 1995.

[21] S. Edwards, S. Demissew, and I. Hedberg, Flora of Ethiopia and Eritrea: Hydrocharitaceae to Arecaceae, Vol. 6, Addis 
Ababa: The National Herbarium, Addis Ababa University, Addis Ababa, Ethiopia, 1997.

[22] S. Edwards, M. Tadesse, S. Demissew, and I. Hedberg, Flora of Ethiopia and Eritrea: Magnoliaceae to Flacourtiaceae, Vol. 2, Addis Ababa: The National Herbarium, Addis Ababa University, Addis Ababa, Ethiopia, 2000.

[23] I. Hedberg and S. Edwards, Flora of Ethiopia: Pittosporaceae to Araliacae, Vol. 3, Addis Ababa: The National Herbarium, Addis Ababa University, Addis Ababa, Ethiopia, 1989.

[24] I. Hedberg, S. Edwards, and S. Nemomissa, Flora of Ethiopia and Eritrea: Apiaceae to Dipsaceae, Vol. 4, Addis Ababa: The National Herbarium, Addis Ababa University, Addis Ababa, Ethiopia, 2003.

[25] I. Hedberg, E. Kelbessa, S. Edwards, S. Demissew, and E. Persson, Flora of Ethiopia and Eritrea, Volume 5, Gentianaceae to Cyclocheilaceae, Vol. 5, Addis Ababa: The National Herbarium, Addis Ababa University, Addis Ababa, Ethiopia, 2006.

[26] J. T. Curtis and R. P. McIntosh, "The interrelations of certain analytic and synthetic phytosociological characters," Ecology, vol. 31, no. 3, pp. 434-455, 1950.

[27] H. Lamprecht, Silviculture in the Tropics: Tropical Forest Ecosystems and Their Tree Species-Possibilities and Methods for Their Long Term Utilization, TZ-Verlagsgesellschaft $\mathrm{GmbH}$, Rossdort, Germany, 1989.

[28] K. Gebrehiwot and K. Hundera, "Species composition, plant community structure and natural regeneration status of Belete moist evergreen montane forest, Oromia regional state, Southwestern Ethiopia," Momona Ethiopian Journal of Science (MEJS), vol. 6, no. 1, pp. 97-101, 2014.

[29] B. Alemu, K. Hundera, and B. Abera, "Floristic composition and structural analysis of Gelesha forest, Gambella regional State, Southwest Ethiopia," Journal of Ecology and The Natural Environment, vol. 7, no. 7, pp. 218-227, 2015.

[30] F. Gurmessa, T. Soromessa, and E. Kelbessa, "Structure and regeneration status of Komto afromontane moist forest, East Wollega Zone, West Ethiopia," Journal of Forestry Research, vol. 23, no. 2, pp. 205-216, 2012.

[31] A. Assefa, S. Demissew, and Z. Woldu, "Floristic composition, structure and regeneration status of Masha forest, South-west Ethiopia," African Journal of Ecology, vol. 52, no. 2, pp. 151-162, 2013.

[32] E. Lulekal, E. Kelbessa, T. Bekele, and H. Yineger, "Plant species composition and structure of the Mana Angetu moist montane forest, South-Eastern Ethiopia," Journal of East African Natural History, vol. 97, no. 2, pp. 165-185, 2008.

[33] P. J. Grubb, J. R. Lloyd, T. D. Pennington, and T. C. Whitmore, "A comparison of montane and lowland rain forest in Ecuador I. The forest structure, physiognomy, and floristics," The Journal of Ecology, vol. 51, no. 3, pp. 567-601, 1963.

[34] S. A. Cain and G. M. d. O. Castro, Manual of Vegetation Analysis, Harper and Brothers, New York, NY, USA, 1959.

[35] J. T. Curtis and R. P. McIntosh, "An upland forest continuum in the prairie-forest border region of Wisconsin," Ecology, vol. 32, no. 3, pp. 476-496, 1951.

[36] L. Poorter, F. Bongers, R. S. A. R. van Rompaey, and M. De Klerk, "Regeneration of canopy tree species at five sites in West African moist forest," Forest Ecology and Management, vol. 84, no. 1-3, pp. 61-69, 1996.

[37] J. W. Silvertown, Introduction to Plant Population Ecology, Longman, London, UK, 1982.

[38] P. Bhuyan, M. L. Khan, and R. S. Tripathi, "Tree diversity and population structure in undisturbed and human impacted stands of tropical wet evergreen forest in Arunachal Pradesh, Eastern Himalayas, India," Biodiversity \& Conservation, vol. 12, pp. 1753-1773, 2003.

[39] A. K. Saxena and J. S. Singh, "Tree population structure of certain Himalayan forest associations and implications concerning their future composition," Vegetatio, vol. 58, no. 2, pp. 61-69, 1984.

[40] A. Abiyu, G. Gratzer, D. Teketay, G. Glatzel, and R. Aerts, "Epiphytic recruitment of schefflera abyssinica (a. rich) harms. and the role of microsites in affecting tree community structure in remnant forests in Northwest Ethiopia," SINET: Ethiopian Journal of Science, vol. 36, no. 1, pp. 41-44, 2013. 